\title{
Effect of nitrogen and lime on Massai grass subjected to intensive cutting ${ }^{1}$
}

\author{
Sandro Cardoso ${ }^{2}$, Edimilson Volpe ${ }^{2}$, Manuel Claudio Motta Macedo ${ }^{3}$
}

\section{ABSTRACT}

Soil acidity and lack of nitrogen fertilization limit the yield of forage grasses. This study aimed at evaluating the effects of lime $\left(0 \mathrm{~kg} \mathrm{ha}^{-1} ; 2,000 \mathrm{~kg} \mathrm{ha}^{-1} ; 4,000 \mathrm{~kg} \mathrm{ha}^{-1}\right.$; and $\left.8,000 \mathrm{~kg} \mathrm{ha}^{-1}\right)$ and nitrogen $\left(0 \mathrm{~kg} \mathrm{ha}^{-1}, 20 \mathrm{~kg} \mathrm{ha}^{-1}, 40 \mathrm{~kg} \mathrm{ha}^{-1}\right.$, $80 \mathrm{~kg} \mathrm{ha}^{-1}$ and $\left.160 \mathrm{~kg} \mathrm{ha}^{-1}\right)$ doses on forage accumulation, soil chemical properties and macronutrient concentrations in leaf blades of Massai grass (Panicum maximum cv. Massai). A randomized blocks design in a $4 \times 5$ factorial scheme, with four replications, was used. Lime and nitrogen doses positively affected the accumulation of green dry mass in the Massai grass as well as the base saturation in the soil. The maximum yield was obtained at nitrogen doses close to $587 \mathrm{~kg} \mathrm{ha}^{-1}$ year $^{-1}$ for nitrogen and $5,796 \mathrm{~kg} \mathrm{ha}^{-1}$ for lime, which produced the greatest accumulation of green dry mass $\left(15,267 \mathrm{~kg} \mathrm{ha}^{-1}\right.$ year $\left.^{-1}\right)$ in the first year of assessment. The demand for lime increased from the first to the second year. Lime increased the base saturation, whereas nitrogen reduced it. The nitrogen applied to the soil raised the nitrogen, magnesium and calcium contents $\left(\mathrm{g} \mathrm{kg}^{-1}\right)$ in the leaf blades of Massai grass. Thus, Massai grass reacted positively to nitrogen and lime doses, with significant effects on the accumulation of green dry mass and soil characteristics assessed.

KEY-WORDS: Panicum maximum cv. Massai; nitrogen fertilization; liming.

\section{INTRODUCTION}

In Brazil, ruminants are fed primarily with pasture containing predominantly grasses. Forage of the Panicum genus is increasingly prominent in pasture-based livestock production systems due to its high forage accumulation potential. However, cultivars of this genus are known for their high

\section{RESUMO}

Efeito de nitrogênio e calcário em capim-massai sob cortes intensivos

A acidez do solo e a ausência de adubação nitrogenada limitam a produtividade de gramíneas forrageiras. Objetivou-se avaliar os efeitos de doses de calcário $\left(0 \mathrm{~kg} \mathrm{ha}^{-1}, 2.000 \mathrm{~kg} \mathrm{ha}^{-1}\right.$, $4.000 \mathrm{~kg} \mathrm{ha}^{-1}$ e $\left.8.000 \mathrm{~kg} \mathrm{ha}^{-1}\right)$ e nitrogênio $\left(0 \mathrm{~kg} \mathrm{ha}^{-1}, 20 \mathrm{~kg} \mathrm{ha}^{-1}\right.$, $40 \mathrm{~kg} \mathrm{ha}^{-1}, 80 \mathrm{~kg} \mathrm{ha}^{-1}$ e $160 \mathrm{~kg} \mathrm{ha}^{-1}$ ) no acúmulo de forragem, atributos químicos do solo e teor de macronutrientes, em lâminas foliares de capim-massai (Panicum maximum cv. Massai). O delineamento experimental foi o de blocos casualizados, em arranjo fatorial 4 x 5, com quatro repetições. As doses de calcário e nitrogênio influenciaram positivamente o acúmulo de massa seca verde do capim-massai e a saturação por bases do solo. A máxima eficiência agronômica foi obtida nas doses estimadas próximas a $587 \mathrm{~kg} \mathrm{ha}^{-1}$ ano $^{-1}$ de nitrogênio e $5.796 \mathrm{~kg} \mathrm{ha}^{-1}$ de calcário, que, no primeiro ano de avaliações, proporcionaram os maiores acúmulos de massa seca verde, com $15.267 \mathrm{~kg} \mathrm{ha}^{-1}$ ano $^{-1}$. Ocorreu elevação na demanda por calcário do primeiro para o segundo ano. Enquanto o calcário elevou a saturação por bases, o nitrogênio causou a redução da mesma. O nitrogênio aplicado ao solo elevou a concentração de nitrogênio, magnésio e cálcio $\left(\mathrm{g} \mathrm{kg}^{-1}\right)$ nas lâminas foliares do capim-massai. Portanto, o capim-massai respondeu positivamente a doses de nitrogênio e calcário, com efeitos significativos no acúmulo de massa seca verde e nas características de solo avaliadas.

PALAVRAS-CHAVE: Panicum maximum cv. Massai; adubação nitrogenada; calagem.

nutrient and management needs (Macedo 2009, Valle et al. 2009), when compared to species and cultivars of Urochloa spp. (Syn: Brachiaria).

Massai grass (Panicum maximum cv. Massai) is a spontaneous hybrid between Panicum maximum and Panicum infestum, commercially launched in 2001 by the Empresa Brasileira de Pesquisa Agropecuária (Embrapa) as a promising alternative

1. Manuscript received in Oct./2015 and accepted for publication in Feb./2016 (http://dx.doi.org/10.1590/1983-40632016v4638132).

2. Agência de Desenvolvimento Agrário e Extensão Rural, Campo Grande, MS, Brasil.

E-mails: sandrocardoso.agraer@gmail.com, edvolpeagraer@gmail.com.

3. Empresa Brasileira de Pesquisa Agropecuária (Embrapa Gado de Corte), Campo Grande, MS, Brasil.

E-mail:manuel.macedo@embrapa.br. 
in the diversification and sustainability of production systems, particularly in the Brazilian Savannah region (Euclides et al. 1995, Volpe et al. 2008).

When compared to other $P$. maximum cultivars, Massai grass stands out for its rapid growth rate, low seasonality (Euclides et al. 2008), greater resistance to drought and froghoppers (Embrapa 2001), high tolerance to acidity (Valentim et al. 2001) and reduced phosphorus $(\mathrm{P})$ content in the soil, since there is no need for fertilizer replenishment (Euclides et al. 2008). As such, Massai grass requires less fertilizer and is therefore more resilient in conditions of low fertility (Embrapa 2001).

Nitrogen $(\mathrm{N})$ is important in more intensive systems and/or soil with a low organic matter content, conditions under which nitrogen topdressing is essential to maintain pasture yield (Volpe et al 2008). Martuscello et al. (2015) reported a high potential response to nitrogen fertilization in Massai grass. However, increased forage production may be limited by low base saturation, when not corrected by liming.

Soil acidity correction positively affects the microbial activity (Albuquerque et al. 2003) and availability of most nutrients in the soil, resulting from the supply of $\mathrm{Ca}$ and $\mathrm{Mg}$ exchanged by $\mathrm{Al}^{3+}$, thereby raising $\mathrm{pH}$, base saturation (Oliveira et al. 2000), accumulation of green dry mass and $\mathrm{N}$ concentration in the leaf blades of Massai grass (Volpe et al. 2008).

This study aimed at assessing the potential response to nitrogen and lime combinations through the green dry mass production, as well as determining the variations in the base saturation of soil and nitrogen, calcium and magnesium contents in leaf blades of Massai grass.

\section{MATERIAL AND METHODS}

The experiment was conducted at the Agência de Desenvolvimento Agrário e Extensão Rural, in Campo Grande, Mato Grosso do Sul State, Brazil, from July 2008 to November 2011. The local climate is typical of the tropical rainy Brazilian Savannah, with an average temperature of $23^{\circ} \mathrm{C}$, according to the Köppen classification, and drought in the fall and winter. Rainfall during the study period was within the normal range (Figure 1).

The soil is characterized as Dystrophic Red Latosol (Oxisol) with a sandy loam texture. In January 2008, prior to the soil preparation, samples were collected at the depth of $0-20 \mathrm{~cm}$ to analyze their chemical and textural properties (Table 1).

The effect of four dolomitic limestone doses with Total Neutralizing Power (TNP) of $100 \%\left(0 \mathrm{~kg} \mathrm{ha}^{-1}\right.$; 2,000 kg ha-1; 4,000 kg ha-1; and 8,000 $\mathrm{kg} \mathrm{ha}^{-1}$ ) and five nitrogen doses $\left(0 \mathrm{~kg} \mathrm{ha}^{-1}, 20 \mathrm{~kg} \mathrm{ha}^{-1}, 40 \mathrm{~kg} \mathrm{ha}^{-1}\right.$, $80 \mathrm{~kg} \mathrm{ha}^{-1}$ and $160 \mathrm{~kg} \mathrm{ha}^{-1}$ ) was evaluated in P. maximum cv. Massai. A randomized blocks design, with four replications and a 4 x 5 factorial scheme, totaling 80 plots, was used. Plots measured $5 \mathrm{~m} \times 5 \mathrm{~m}$, with a $1 \mathrm{~m}$ border. The total experiment area was $3,000 \mathrm{~m}^{2}$, with $1,280 \mathrm{~m}^{2}$ of useful area.

Liming was carried out in December 2008. Lime doses of $8,000 \mathrm{~kg} \mathrm{ha}^{-1}$ were divided into two $4,000 \mathrm{~kg} \mathrm{ha}^{-1}$ applications, thirty days apart. Approximately twenty days after liming, the soil in all plots was fertilized with $200 \mathrm{~kg} \mathrm{ha}^{-1}$ of $\mathrm{K}_{2} \mathrm{O}$, $200 \mathrm{~kg} \mathrm{ha}^{-1}$ of $\mathrm{P}_{2} \mathrm{O}_{5}$ and $1,000 \mathrm{~kg} \mathrm{ha}^{-1}$ of the $00-20-20$

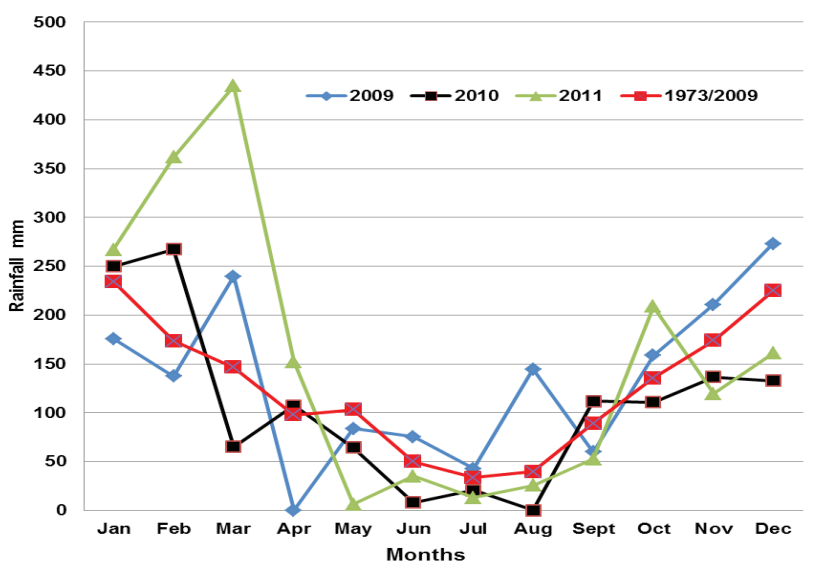

Figure 1. Monthly rainfall in 2009, 2010, 2011 and from 1973 to 2009 (Campo Grande, Mato Grosso do Sul State, Brazil). Source: Embrapa Gado de Corte Weather Station.

Table 1. Chemical properties of the experimental soil at 0-20 cm depth (Campo Grande, Mato Grosso do Sul State, Brazil, 2008).

\begin{tabular}{|c|c|c|c|c|c|c|c|c|c|c|}
\hline $\mathrm{pH}$ & $\mathrm{MO}$ & $\mathrm{Ca}^{++}$ & $\mathrm{Mg}^{++}$ & $\mathrm{K}^{+}$ & $\mathrm{PM}_{1}$ & $\mathrm{Al}^{+3}$ & $\mathrm{H}+\mathrm{Al}$ & $\mathrm{S}$ & $\mathrm{T}$ & $\mathrm{V}$ \\
\hline $\mathrm{CaCl}_{2}$ & $(\%)$ & 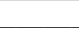 & $\mathrm{nol}_{\mathrm{c}} \mathrm{dm}$ & & $\mathrm{mg} \mathrm{dm}^{-3}$ & 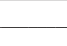 & $\mathrm{cmc}$ & $\mathrm{n}^{-3}$ & & $\%$ \\
\hline 4.77 & 4.16 & 2.04 & 0.86 & 0.23 & 1.46 & 0.35 & 5.66 & 3.14 & 8.79 & 36 \\
\hline
\end{tabular}

$\mathrm{PM}_{1}=$ phosphorous $\left(\right.$ Mehlich $\left.^{-1}\right)$. 
formula, with $100 \mathrm{~kg} \mathrm{ha}^{-1}$ of sulfur (S) and the following micronutrients: molybdenum (sodium molybdate), zinc and copper (sulfates) and boron (borax), at doses of $0.2 \mathrm{~kg} \mathrm{ha}^{-1}, 4.0 \mathrm{~kg} \mathrm{ha}^{-1}, 2.0 \mathrm{~kg} \mathrm{ha}^{-1}$ and $1.0 \mathrm{~kg} \mathrm{ha}^{-1}$, respectively.

In January 2009, around 40 days after liming, Massai grass seeds were planted in rows spaced $20 \mathrm{~cm}$ apart, using $3 \mathrm{~kg} \mathrm{ha}^{-1}$ of pure and viable seeds. At the end of the rainy season, in May 2009, May 2010 and March 2011, soil samples were collected from all plots, at a depth of $0-20 \mathrm{~cm}$, to determine $\mathrm{pH}$ $\left(\mathrm{CaCl}_{2}\right), \mathrm{MO}, \mathrm{Ca}^{++}, \mathrm{Mg}^{++}, \mathrm{K}^{+}, \mathrm{P}, \mathrm{Al}^{+3}, \mathrm{H}+\mathrm{Al}, \mathrm{SB}, \mathrm{T}$ and $\mathrm{V} \%$ (base saturation) (Embrapa 1997).

A cut-off point was established for standardization purposes in October 2009, with two cut-off points for assessment in 2009 (November and December), six in 2010 (January, March, April, June, October and December) and five in 2011 (January, February, March, May and November), totaling 13 cut-off points. Thus, three cut-offs were made during the dry season, with little or no rainfall (June and October 2009 and November 2011), and the remainder (10) in the rainy season.

In order to assess the total biomass and morphological components of the forage, the grass was cut at a height of $15 \mathrm{~cm}$ off the ground, in a $4 \mathrm{~m}^{2}$ area, at intervals of approximately 35 days, in the rainy season of both years, and 110 and 180 days during the dry season, in the first (2010) and second year (2011), respectively, as a function of plant growth. The biomass components evaluated were: leaf blades (LB), stem and sheath (SS) and senescent material (SM). Green dry mass (GDM) was composed of LB + SS. The forage growth period, during the rainy season, was 28 days between cut-offs. After each cut-off for assessment, cattle were placed in the experimental area to even out the forage by grazing. The animals were removed from the area when grass height was close to $15 \mathrm{~cm}$, after approximately seven days.

Nitrogen topdressing was performed during the rainy season only, at each assessment cut-off, after the cattle were removed, using urea as a source and in accordance with predetermined amounts. In addition, $\mathrm{N}, \mathrm{K}_{2} \mathrm{O}$ (potassium oxide) and $\mathrm{P}_{2} \mathrm{O}_{5}$ (triple superphosphate) were applied in the amount needed to replenish the nutrients removed by the forage produced, considering a removal of $2.0 \%$ of $\mathrm{K}$ and $0.15 \%$ of P from each $\mathrm{kg} \mathrm{ha}^{-1}$ of forage (Souza \& Lobato 2004).
To determine the $\mathrm{N}$, calcium and magnesium contents in the leaf blades, material to compile two samples was collected one day before cutting, in January 2010 and 2011 (rainy season) and June and November 2010 and 2011 (dry season). The samples were analyzed separately during the dry season and together in the rainy seasons of 2010 and 2011. Approximately 100 leaf blades were collected from each plot (Monteiro 2005), pre-dried $\left(55^{\circ} \mathrm{C}\right)$ until constant weight, ground and submitted to macronutrient analysis $(\mathrm{P}, \mathrm{Ca}, \mathrm{Mg}, \mathrm{S}$ and $\mathrm{K})$, in accordance with Sarruge \& Haag (1974), except for $\mathrm{N}$, which was determined by near-infrared spectroscopy (NIRS) in line with the procedures of Marten et al. (1985).

The data obtained were submitted to analyses of variance and, when significant $(\mathrm{p}<0.01$ and $\mathrm{p}<0.05$ ), regression analyses were conducted using the Saeg statistical software (Ribeiro Júnior 2001). In the regression analyses, responses were adjusted as a function of the means, adopting only coefficients identified as significant by the $t$ test $(p<0.10)$.

\section{RESULTS AND DISCUSSION}

There was no interaction between lime and nitrogen levels in any of the variables analyzed. Nitrogen and lime had a significant effect on the accumulation of green dry mass (GDM) in Massai grass, during the rainy season of the first year (Figure 2). However, only nitrogen was significant during both the dry and rainy seasons of this same year (Figure 3). Estimated accumulated doses of $607 \mathrm{~kg} \mathrm{ha}^{-1}$ year $^{-1}$ of nitrogen and $3,855 \mathrm{~kg} \mathrm{ha}^{-1}$ of calcium promoted greater GDM accumulation $\left(11,077 \mathrm{~kg} \mathrm{ha}^{-1}\right)$ in the rainy season, whereas $587 \mathrm{~kg} \mathrm{ha}^{-1}$ year-1 $^{-1}$ of nitrogen resulted in the highest GDM accumulation $\left(15,263 \mathrm{~kg} \mathrm{ha}^{-1}\right.$ year $\left.^{-1}\right)$ in the period covering both seasons.

In the second year of the study (dry and rainy), the GDM accumulation ( $\mathrm{kg} \mathrm{ha}^{-1}$ year $^{-1}$ ) of Massai grass responded positively to nitrogen and lime (Figure 4). During this period, estimated nitrogen doses of $570 \mathrm{~kg} \mathrm{ha}^{-1}$ year $^{-1}$ and $5,796 \mathrm{~kg} \mathrm{ha}^{-1}$ of lime led to higher GDM accumulation $\left(15,147 \mathrm{~kg} \mathrm{ha}^{-1}\right.$ year $\left.^{-1}\right)$.

Kichel et al. (2004) also found that nitrogen doses close to those studied here produced maximum yield with greater forage GDM accumulation, in Massai grass grown in a greenhouse. 
The authors of this study observed that the estimated nitrogen levels that produced the highest GDM accumulation in both study periods were similar. However, the need for liming rose by $1,941 \mathrm{~kg} \mathrm{ha}^{-1}$ in the same period (2009/2010 to 2010/2011).

Among the likely causes of the estimated increase in liming and nitrogen fertilization from

$\hat{\mathrm{y}}=3210.09+25.07 * * \mathrm{x}-0.02064 * * \mathrm{x}^{2}+0.13062 * \mathrm{z}-0.00001694^{0} \mathrm{z}^{2} \quad \mathrm{R}^{2}=0.99$ **, *, ${ }^{0}$ significant at $1 \%, 5 \%$ and $10 \%$, respectively, according to the t test $\mathrm{x}=$ nitrogen; $\mathrm{z}=$ lime

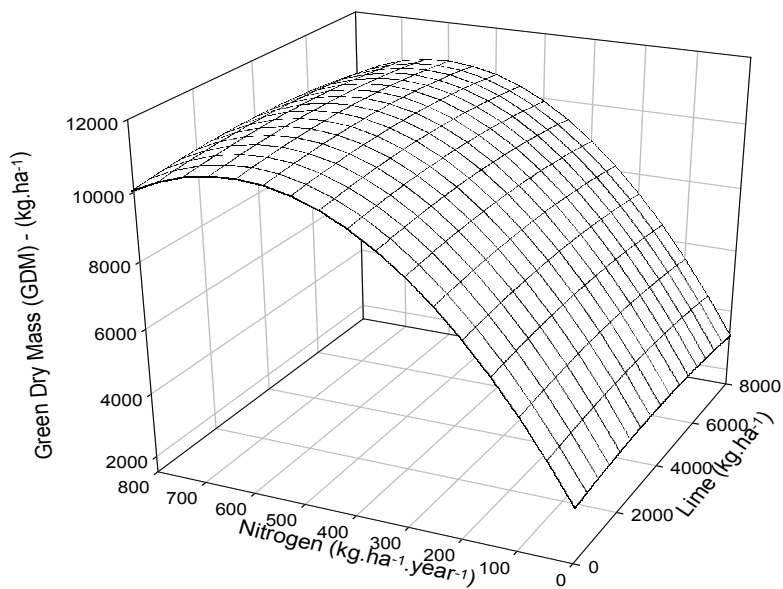

Figure 2. Accumulation of green dry mass of Massai grass, as a function of nitrogen and lime, during the 2009/2010 rainy season (Campo Grande, Mato Grosso do Sul State, Brazil). the first to the second year is soil acidification, which occurred throughout the study period as a result of successive $\mathrm{N}$ application, requiring higher doses of lime to maintain the same forage production and reduce soil acidification, neutralizing $\mathrm{H}^{+}$and $\mathrm{Al}^{+3}$. It can be reasonably assumed that, during the maintenance phase of intensive systems based on high nitrogen doses, demand for lime will be greater than the levels currently recommended to sustain high green dry mass accumulation.

Considering the initial soil analysis, in order to achieve the recommended base saturation for Massai grass (40\%) (Embrapa 2001), around $300 \mathrm{~kg} \mathrm{ha}^{-1}$ would be needed (base saturation method) in the implementation phase of the present study. Nevertheless, the highest biomass accumulation in this period was recorded at a lime dose of $3,855 \mathrm{~kg} \mathrm{ha}^{-1}$. The highest amount of lime estimated in this study is possibly related to the effects of urea $\left(\mathrm{H}^{+}\right)$in soil acidification, what was also observed by Costa et al. (2008), in bread grass.

It can be inferred that the demand for $\mathrm{Ca}$ and $\mathrm{Mg}$ may be lower in the implementation phase of Massai grass, particularly with smaller doses of $\mathrm{N}$, which may not occur during the maintenance phase under favorable temperature and humidity conditions with high $\mathrm{N}$ levels. $\hat{\mathrm{y}}=4443.12+36.8296 * * \mathrm{x}-0.03134 * * \mathrm{x}^{2} \mathrm{R}^{2}=0.99$ ** significant at $1 \%$, according to the $\mathrm{t}$ test

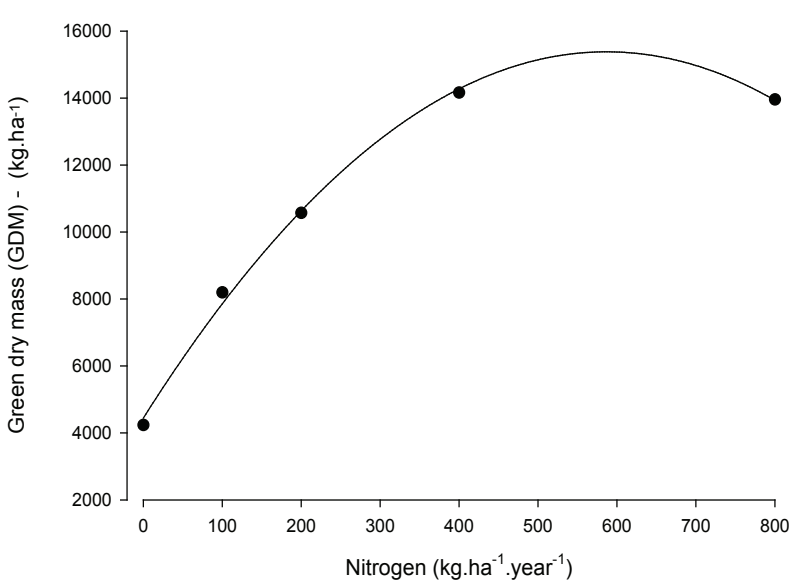

Figure 3. Accumulation of green dry mass of Massai grass, as a function of nitrogen, during the 2009/2010 dry and rainy seasons (Campo Grande, Mato Grosso do Sul State, Brazil). $\hat{y}=1416.11+46.02 * * x-0.04035^{* *} x^{2}+0.209839 * z-0.00001810^{0} z^{2} \quad R^{2}=0.99$ , isnificant at $10 \%, 5 \%$ and $1 \%$, respectively, according to the $t$ test $\mathrm{x}=$ nitrogen; $\mathrm{z}=$ lime

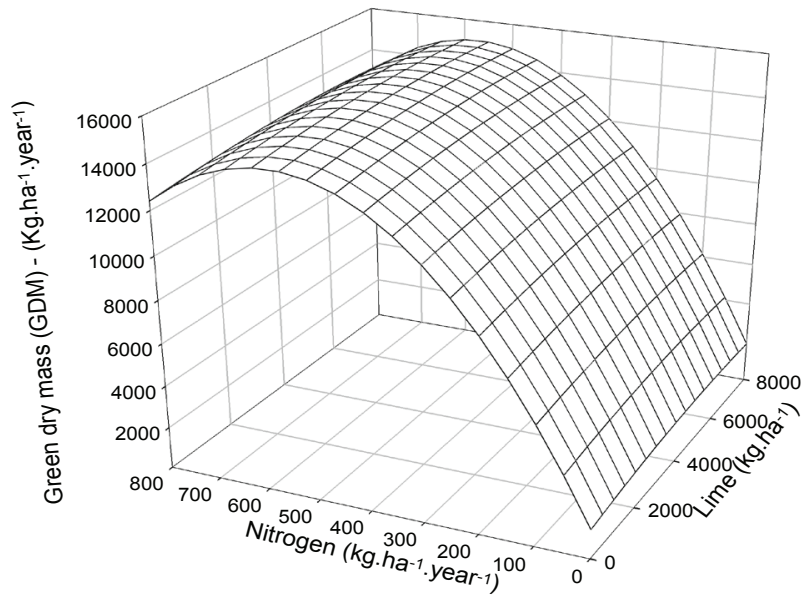

Figure 4. Accumulation of green dry mass of Massai grass, as a function of nitrogen and lime, in the second year (2010/2011) (Campo Grande, Mato Grosso do Sul State, Brazil). 
In 2009, the soil base saturation (V\%) was altered only by lime and remained unchanged by nitrogen (Figure 5). A V\% of 61 was estimated at the highest lime dose $\left(8,000 \mathrm{~kg} \mathrm{ha}^{-1}\right)$. It is important to note that nitrogen (urea) topdressing had yet to be applied during this period and therefore did not change base saturation.

Thus, nitrogen was only found to affect V\% in 2010 and 2011 (Figure 6), possibly due to the successive high nitrogen doses applied to the soil

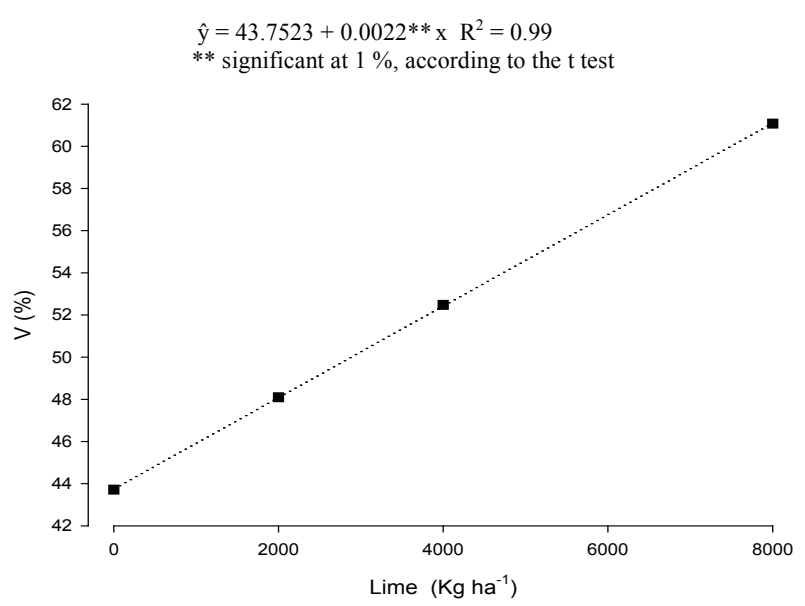

Figure 5. Base saturation (V\%) in the soil (2009), as a function of lime doses, in Massai grass (Campo Grande, Mato Grosso do Sul State, Brazil).

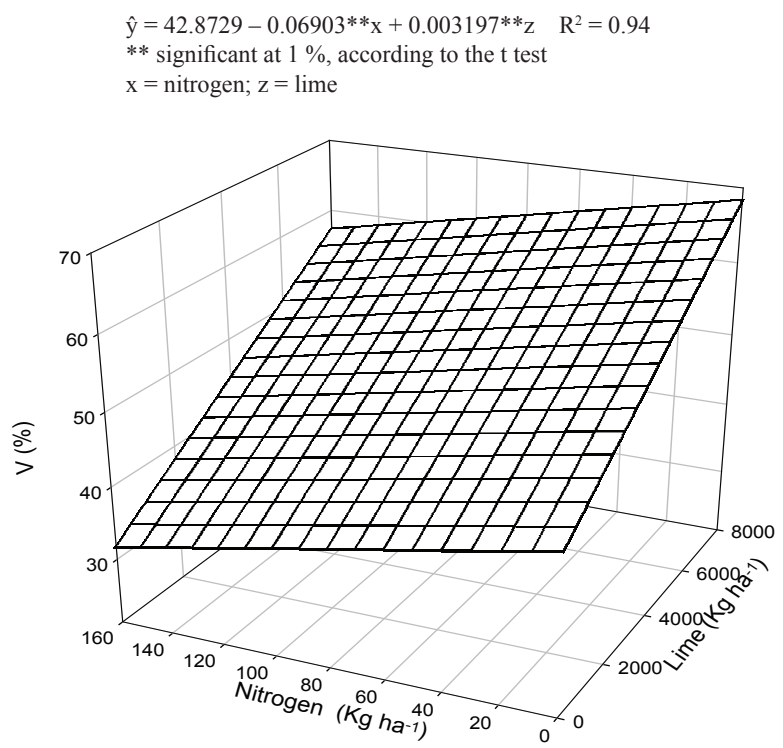

Figure 6. Base saturation (V\%) in the soil (2010), as a function of nitrogen and lime doses, in Massai grass (Campo Grande, Mato Grosso do Sul State, Brazil). during the study period. In 2010, V\% was linearly influenced by both nitrogen and lime. A V\% of 57 was estimated at the highest nitrogen $\left(160 \mathrm{~kg} \mathrm{ha}^{-1}\right)$ and lime $\left(8,000 \mathrm{~kg} \mathrm{ha}^{-1}\right)$ doses.

In 2011, nitrogen doses also decreased the $\mathrm{V} \%$, while lime raised the base saturation (Figure 7), as occurred in the previous year. A V\% of 53 was estimated at the highest doses of nitrogen $\left(160 \mathrm{~kg} \mathrm{ha}^{-1}\right)$ and lime $\left(6,224.45 \mathrm{~kg} \mathrm{ha}^{-1}\right)$, in 2011. Similar effects on base saturation by lime and nitrogen were reported by Primavesi et al. (2004), in a study with signal grass (Urochloa decumbens cv. Basilisk). Moreover, in both years of the study, the estimated $\mathrm{V} \%$ at accumulated nitrogen doses that yielded the highest GDM accumulation was above $50 \%$, meaning that the increase in forage production was the result of high $\mathrm{N}$ doses, which raised the demand for other nutrients, especially $\mathrm{Ca}$ and $\mathrm{Mg}$. Thus, higher doses of lime would be needed to sustain an increased production.

The authors of studies on Tifton 85 Bermuda grass (Cynodon spp.) recommend a $\mathrm{V} \%$ above 50 (Prado \& Barion 2009). As such, it seems relevant to raise the $\mathrm{V} \%$ above 50 , during the growth phase of Massai grass under intensive production systems using successive high doses of nitrogen after defoliation.

In general, the increase in dry mass accumulation results from a set of factors, among
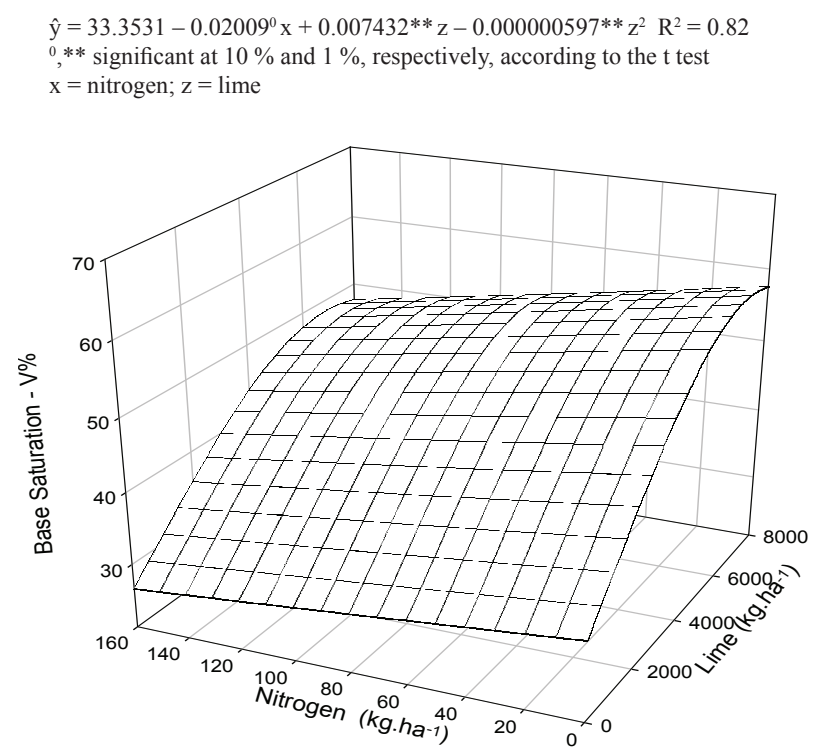

Figure 7. Base saturation in the soil (2011), as a function of nitrogen and lime, in Massai grass (Campo Grande, Mato Grosso do Sul State, Brazil). 
which liming plays an important role due to the rise in $\mathrm{pH}$, base saturation, decline in toxic aluminum in the soil and decreased $\mathrm{Ca}$ and $\mathrm{Mg}$ contents, favoring the development of forage species.

Calcium and magnesium contents in the soil increased linearly in 2009 and 2010, as liming increased (Figures 8 and 9). Maximum $\mathrm{Ca}$ concentrations close to $3.12 \mathrm{cmol}_{\mathrm{c}} \mathrm{dm}^{-3}$ and

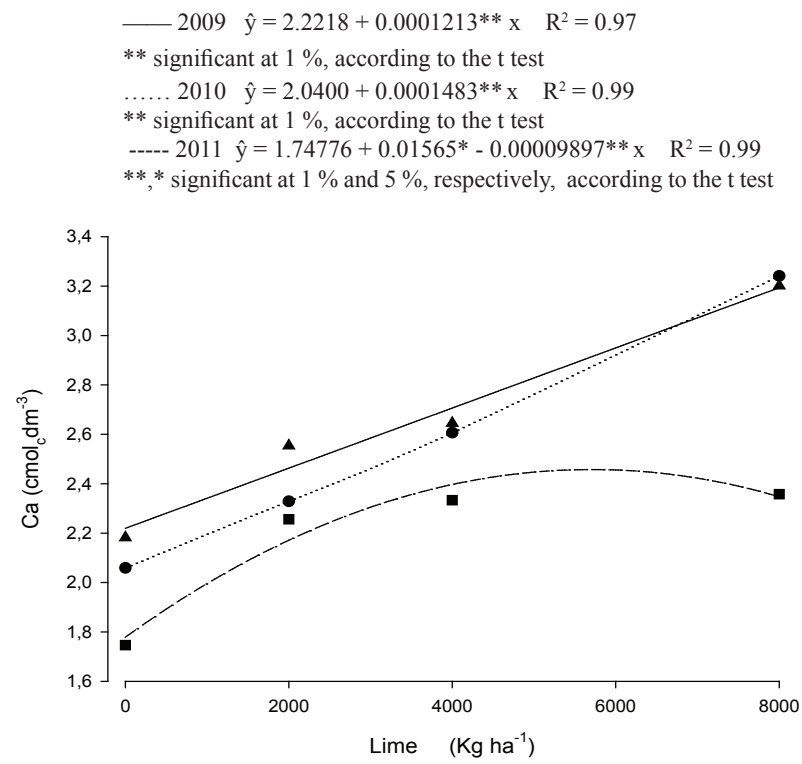

Figure 8. Calcium in the soil (2009, 2010 and 2011), as a function of lime doses, in Massai grass (Campo Grande, Mato Grosso do Sul State, Brazil).
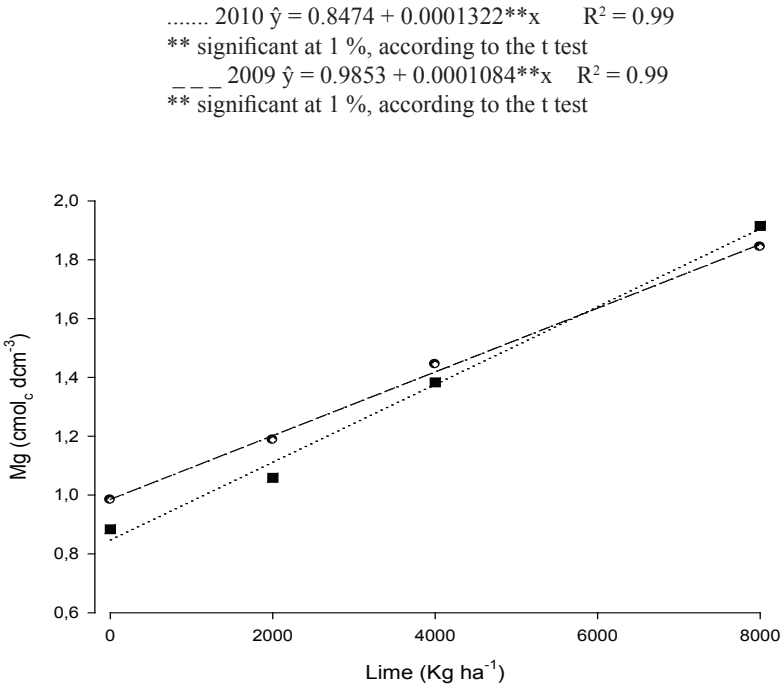

Figure 9. Mg in the soil (2009 and 2010), as a function of lime doses, in Massai grass (Campo Grande, Mato Grosso do Sul State, Brazil).
$3.23 \mathrm{cmol}_{\mathrm{c}} \mathrm{dm}^{-3}$ were obtained at the highest lime doses in 2009 and 2010, respectively, above the critical level established by Sousa \& Lobato (2004) $\left(<1.5 \mathrm{cmol}_{\mathrm{c}} \mathrm{dm}^{-3}\right.$ for $\mathrm{Ca}$ and $<0.5 \mathrm{cmol}_{\mathrm{c}} \mathrm{dm}^{-3}$ for $\left.\mathrm{Mg}\right)$, even in the absence of lime. These results indicate that initial lime content in the soil prior to the experiment was already above the critical level.

In 2011, the different lime doses initially applied to the soil significantly altered (quadratic effect) calcium and magnesium levels, with magnesium also affected by nitrogen (Figures 8 and 10).

Calcium and magnesium levels, in 2011, were lower than those recorded in 2009 and 2010, with average calcium concentrations of $2.65 \mathrm{cmol}_{\mathrm{c}} \mathrm{dm}^{-3}$, $2.56 \mathrm{cmol}_{\mathrm{c}} \mathrm{dm}^{-3}$ and $2.17 \mathrm{cmol}_{\mathrm{c}} \mathrm{dm}^{-3}$, and magnesium contents of $1.37 \mathrm{cmol}_{\mathrm{c}} \mathrm{dm}^{-3}, 1.31 \mathrm{cmol}_{\mathrm{c}} \mathrm{dm}^{-3}$ and $1.03 \mathrm{cmol}_{\mathrm{c}} \mathrm{dm}^{-3}$, for 2009, 2010 and 2011, respectively. The low average calcium levels recorded in the soil, in 2011, may have occurred because lime reached the maximum reaction rate, combined with the acidifying effect of nitrogen (urea) and leaching. This results in quadratic response curves for levels of these elements ( $\mathrm{Ca}$ and $\mathrm{Mg}$ ) in 2011, if compared to the linear curves seen in 2009 and 2010. A similar behavior was observed by Ferreira \& Macedo (2006), who studied the effects of liming on Massai grass.

Nitrogen content in the leaf blades was not affected by liming and rose as nitrogen doses increased. Data obtained in 2010 for leaf blades fit a linear model in the rainy season and a quadratic

\section{$\hat{y}=0.8597-0.0003938 * x-0.00001876 * x^{2}+0.0001631 * * z-0.00000001350 * * z^{2}$ $\mathrm{R}^{2}=0.61$ \\ *** significant at $5 \%$ and $1 \%$, respectively, according to the $t$ test}

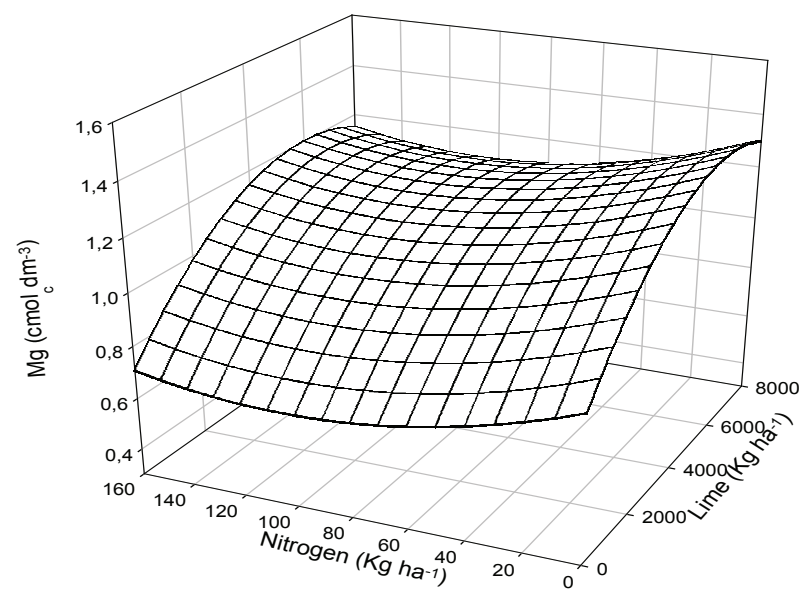

Figure 10. Mg in the soil (2011), as a function of lime and nitrogen doses, in Massai grass (Campo Grande, Mato Grosso do Sul State, Brazil). 
model during the dry period (Figure 11). A similar behavior was observed in 2011, when nitrogen levels in the leaf blades rose as the nitrogen dose increased, following a linear format in both periods assessed (Figure 12).

The highest estimated nitrogen content in leaf blades was $26 \mathrm{~g} \mathrm{~kg}^{-1}$ for a nitrogen dose of $160 \mathrm{~kg} \mathrm{ha}^{-1}$ and $24 \mathrm{~g} \mathrm{~kg}^{-1}$ at a dose of $128 \mathrm{~kg} \mathrm{ha}^{-1}$ in the rainy (January) and dry season (June), respectively, in 2010, while, in 2011, the highest nitrogen concentrations in blades were $23 \mathrm{~g} \mathrm{~kg}^{-1}$ and $26 \mathrm{~g} \mathrm{~kg}^{-1}$, at an estimated dose of $160 \mathrm{~kg} \mathrm{ha}^{-1}$, in both the rainy (January) and dry season (November), respectively.

Lavres Júnior \& Monteiro (2006) reported higher nitrogen levels in the leaf blades of Panicum maximum cv. Aruana as nitrogen doses increased. When comparing the lowest critical nitrogen level recorded in Mombasa guinea grass (Panicum maximum cv. Mombaça) (16 $\mathrm{g} \mathrm{kg}^{-1}$ and $\left.16.5 \mathrm{~g} \mathrm{~kg}^{-1}\right)$ by Manarim \& Monteiro (2002) with the estimates for Massai grass in the present study, calculated by regression equations as a function of $\mathrm{N}$ doses, we found that nitrogen deficiency did not occur in the first year of assessment (2010).

In 2011, nitrogen doses of $0 \mathrm{~kg} \mathrm{ha}^{-1}, 20 \mathrm{~kg} \mathrm{ha}^{-1}$ and $40 \mathrm{~kg} \mathrm{ha}^{-1}$ generated below-critical nitrogen concentrations in Massai grass blades, during the dry season, of $14.0 \mathrm{~g} \mathrm{~kg}^{-1}, 15.0 \mathrm{~g} \mathrm{~kg}^{-1}$ and $15 \mathrm{~g} \mathrm{~kg}^{-1}$, respectively. In the rainy season, only nitrogen

.... Rainy season $\hat{y}=16.0061+0.0614 * * x \quad R^{2}=0.99$

** significant at $1 \%$, according to the $t$ test

Dry season $\hat{y}=12.4475+0.1796 * x-0.0007 * * x^{2} \quad R^{2}=0.99$

*** significant at $5 \%$ and $1 \%$, respectively, according to the $t$ test

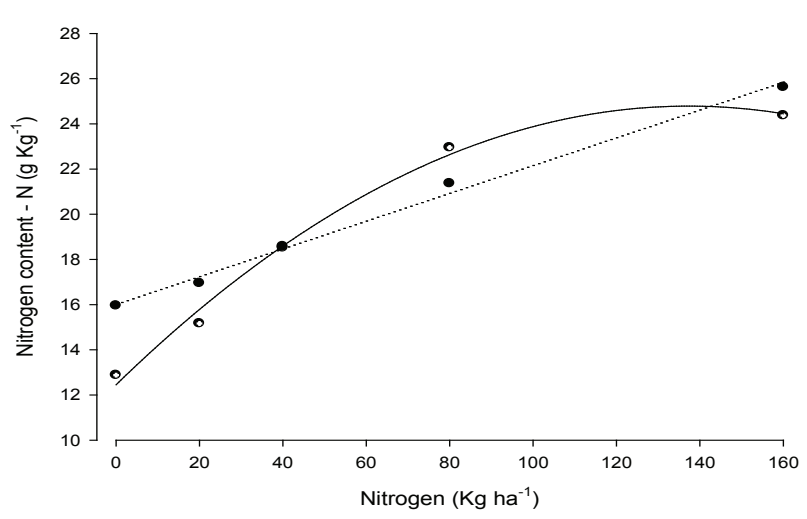

Figure 11. Nitrogen content in Massai grass blades, during the dry and rainy seasons (January-June 2010) of the first year, as a function of nitrogen doses (Campo Grande, Mato Grosso do Sul State, Brazil). doses of $0 \mathrm{~kg} \mathrm{ha}^{-1}$ and $20 \mathrm{~kg} \mathrm{ha}^{-1}$ resulted in nitrogen concentrations below the critical level $\left(15.0 \mathrm{~g} \mathrm{~kg}^{-1}\right.$ and $15.5 \mathrm{~g} \mathrm{~kg}^{-1}$, respectively), considering those reported for Mombasa guinea grass as reference.

In addition to the nitrogen dose applied, climate may also have interfered in the nitrogen content of leaf blades, with high absorption under favorable temperature and moisture conditions, during the rainy season, for both years of the study.

Although calcium and magnesium contents in the soil increased as a result of liming, levels of these elements in leaf blades in 2010 and 2011 (dry and rainy seasons) and magnesium in 2011 (rainy season) were not affected by liming. Both lime and nitrogen increased magnesium levels during the dry season of 2011.

Typically, high lime doses are expected to alter calcium and magnesium levels in the leaf tissue of forage species (Volpe et al. 2008). However, this did not occur in the present study likely because initial calcium $\left(2.04 \mathrm{cmol}_{\mathrm{c}} \mathrm{dm}^{-3}\right)$ and magnesium $\left(0.86 \mathrm{cmol}_{\mathrm{c}} \mathrm{dm}^{-3}\right)$ concentrations in the soil met the requirements of Massai grass and remained above the critical levels recommended by Monteiro (2005): $4.0 \mathrm{~g} \mathrm{~kg}^{-1}$ for calcium and 1.5-4.2 $\mathrm{g} \mathrm{kg}^{-1}$ for magnesium in leaf blades. These levels continued to rise in the soil after liming.

Nitrogen applied to the soil linearly increased the magnesium content in the leaf blades of Massai

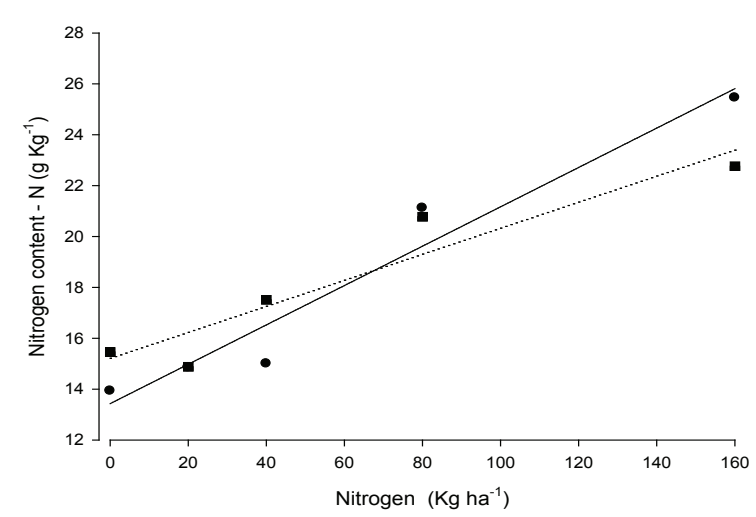

Figure 12. Nitrogen content in Massai grass blades, during the dry and rainy seasons (January-November 2011) of the second year, as a function of nitrogen doses (Campo Grande, Mato Grosso do Sul State, Brazil). 
grass during the dry and rainy seasons of 2010 (Figure 13) and the dry period of 2011 (Figure 14).

Calcium levels in leaf blades only exhibited a positive linear response to nitrogen fertilization during the dry season of the final year (2011).

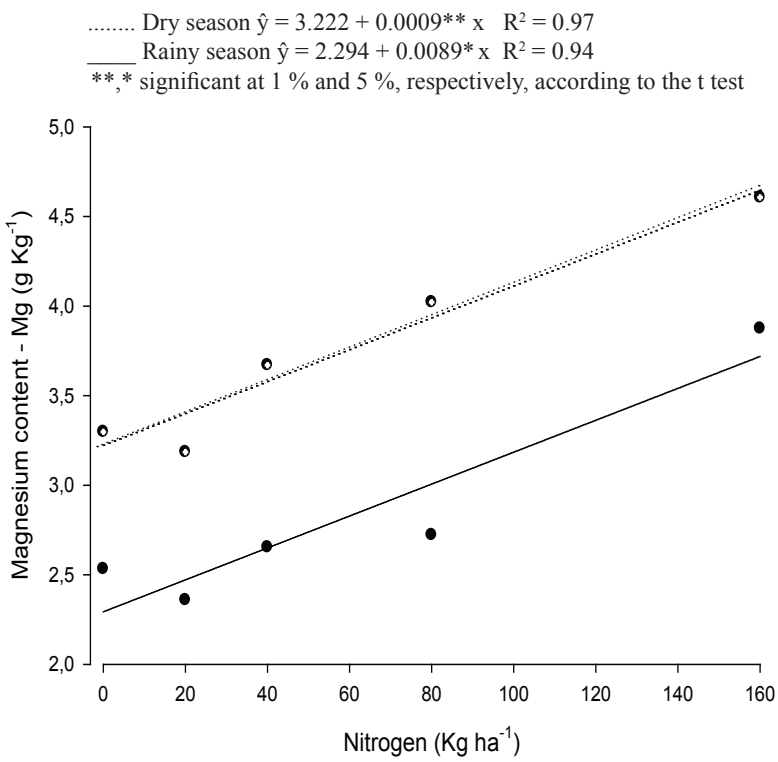

Figure 13. Magnesium content in Massai grass blades, during the dry and rainy seasons (January-June 2010) of the first year, as a function of nitrogen doses (Campo Grande, Mato Grosso do Sul State, Brazil).

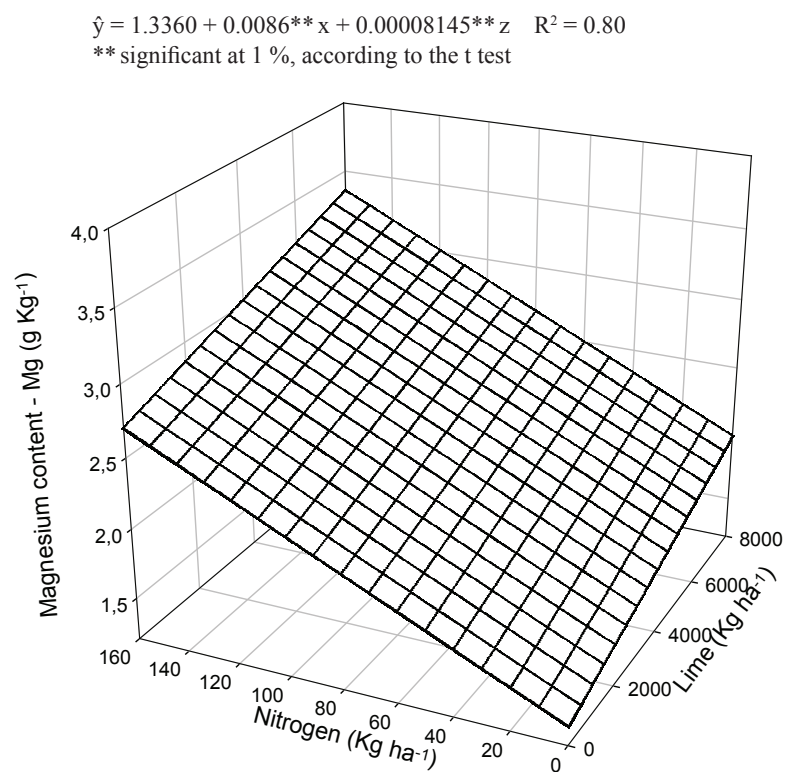

Figure 14. Magnesium content in Massai grass blades, during the dry season (November 2011) of the second year, as a function of nitrogen and lime doses (Campo Grande, Mato Grosso do Sul State, Brazil).

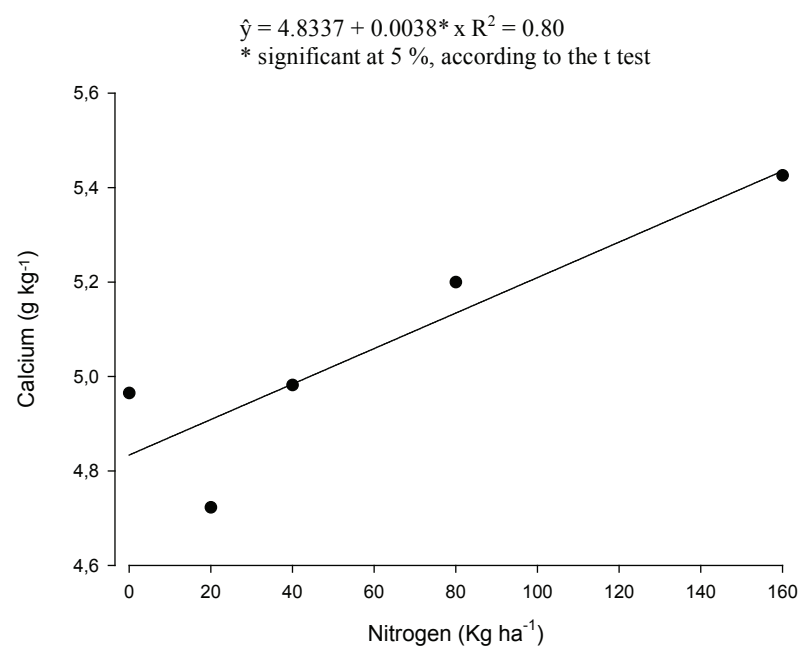

Figure 15. Calcium content in Massai grass blades, during the dry season (November 2011) of the second year, as a function of nitrogen doses (Campo Grande, Mato Grosso do Sul State, Brazil).

Volpe et al. (2008) and Costa et al. (2009) reported a greater extraction and high nitrogen, calcium and magnesium levels in the leaf blades of forage due to nitrogen fertilization. Primavesi et al. (2005) studied coastcross grass (Cynodon dactylon) and found that applying urea to soil raised the absorption of cations and anions.

The fact that nitrogen raised the magnesium content in Massai grass leaf blades in three of the four assessment periods and calcium in only one may be due to increased photosynthesis and, consequently, higher chlorophyll $(\mathrm{Mg})$ levels, since magnesium is more closely related to chlorophyll than calcium.

\section{CONCLUSIONS}

1. Increasing doses of nitrogen and lime raise the green dry mass accumulation in Massai grass subject to intensive cutting.

2. While lime increases base saturation and calcium and magnesium content in the soil, nitrogen has the opposite effect on base saturation.

3. Nitrogen, calcium and magnesium levels in the leaf blades of Massai grass are more affected by nitrogen applied to the soil than lime.

\section{REFERENCES}

ALBUQUERQUE, J. A. et al. Aplicação de calcário e fósforo e estabilidade da estrutura de um solo ácido. 
Revista Brasileira de Ciência do Solo, Viçosa, n. 27, n. 5, p. 799-806, 2003.

COSTA, K. A. P. et al. Doses e fontes de nitrogênio em pastagem de capim-marandu: alterações nas características químicas do solo. Revista Brasileira de Ciência do Solo, Viçosa, v. 32, n. 4, p. 1591-1599, 2008.

COSTA, K. A. P. et al. Extração de nutrientes do capimmarandu sob doses e fontes de nitrogênio. Revista Brasileira de Saúde e Produção Animal, Salvador, v. 10, n. 4, p. 801-812, 2009.

EMPRESA BRASILEIRA DE PESQUISA AGROPECUÁRIA (Embrapa). Capim Massai (Panicum maximum cv Massai): alternativa para diversificação de pastagens. Campo Grande: Embrapa Gado de Corte, 2001. (Comunicado técnico, 69).

EMPRESA BRASILEIRA DE PESQUISA AGROPECUÁRIA (Embrapa). Manual de métodos de análise de solo. 2. ed. Rio de Janeiro: Embrapa Solos, 1997. (Documentos, 1).

EUCLIDES, V. P. B.; MACEDO, M. C. M.; OLIVEIRA, M. P. Avaliação de ecotipos de Panicum maximum sob pastejo em pequenas parcelas. In: REUNIÃO ANUAL DA SOCIEDADE BRASILEIRA DE ZOOTECNIA, 32. 1995, Brasília. Anais... Brasília, DF: Sociedade Brasileira de Zootecnia, 1995. p. 97-99.

EUCLIDES, V. P. B. et al. Avaliação dos capins mombaça e massai sob pastejo. Revista Brasileira de Zootecnia, Viçosa, v. 37, n. 1, p. 18-26, 2008.

FERREIRA, R. B.; MACEDO, M. C. M. Avaliação da produção do capim-massai sob doses crescentes de calcário em solo arenoso. Ensaios e Ciência, Valinhos, v. 10, n. 1, p. 21-32, 2006.

KICHEL, A. G.; MIRANDA, C. H. B.; LEMPP, B. Acúmulo de matéria seca e nitrogênio e perfilhamento de Panicum maximum cv. Massai em função de doses crescentes de nitrogênio. In: REUNIÃO ANUAL DA SOCIEDADE BRASILEIRA DE ZOOTECNIA, 41., 2004, Campo Grande. Anais ... Campo Grande: Sociedade Brasileira de Zootecnia, 2004. 1 CD-ROM.

LAVRES JÚNIOR, J.; MONTEIRO, F. A. Diagnose nutricional de nitrogênio no capim-aruana em condições controladas. Revista Brasileira de Ciência do Solo, Viçosa, v. 30, n. 5, p. 829-837, 2006.

MACEDO, M. C. M. Integração lavoura e pecuária: o estado da arte e inovações tecnológicas. Revista Brasileira de Zootecnia, Viçosa, v. 38, supl. esp., p. 133-146, 2009.

MANARIM, C. A.; MONTEIRO, F. A. Nitrogênio na produção e diagnose foliar do capim-mombaça. Boletim da Indústria Animal, Nova Odessa, v. 59, n. 2, p. 115123, 2002.
MARTEN, G. C.; SHENK, J. S.; BARTONII, F. E. Near infrared reflectance spectroscopy (NIRS): analysis quality. Washington, DC: USDA, 1985. (Agriculture handbook, 643).

MARTUSCELLO, J. A. et al. Adubação nitrogenada em capim-massai: morfogênese e produção. Ciência Animal Brasileira, Goiânia, v. 16, n. 1, p. 1-13, 2015.

MONTEIRO, F. A. Amostragem de solo e de planta para fins de análises químicas: método de interpretação de resultados. In: SIMPÓSIO SOBRE MANEJO DE PASTAGENS: TEORIA E PRÁTICA DA PRODUÇÃO ANIMAL EM PASTAGENS, 22., 2005, Piracicaba. Anais... Piracicaba: Fundação de Estudos Agrários Luiz de Queiroz, 2005. p. 151-180.

OLIVEIRA, I. P. et al. Avaliação da calagem sobre os parâmetros quantitativos, qualitativos e nutricionais da forrageira Tanzânia-1. Pesquisa Agropecuária Tropical, Goiânia, v. 30, n. 1, p. 71-75, 2000.

PRADO, R. M.; BARION, R. D. Efeitos da calagem na nutrição e produção de massa seca do capim-tifton 85 . Pesquisa Agropecuária Tropical, Goiânia, v. 39, n. 3, p. 218-224, 2009.

PRIMAVESI, A. C. et al. Absorção de cátions e ânions pelo capim-coastcross adubado com ureia e nitrato de amônio. Pesquisa Agropecuária Brasileira, Brasília, DF, v. 40, n. 3, p. 247-253, 2005.

PRIMAVESI, O. et al. Calagem em pastagem de Brachiaria decumbens recuperada com adubação nitrogenada em cobertura. São Carlos: Embrapa Pecuária Sudeste, 2004. (Circular técnica, 37).

RIBEIRO JÚNIOR, J. I. Análises estatísticas no Saeg. Viçosa: UFV, 2001.

SARRUGE, J. R.; HAAG, H. P. Análises químicas em plantas. Piracicaba: ESALQ, 1974.

SOUSA, D. M.; LOBATO, E. Cerrado: correção do solo e adubação. Planaltina: Embrapa Cerrados, 2004.

VALENTIM, J. F. et al. Capim massai (Panicum maximum jacq.): nova forrageira para a diversificação das pastagens no Acre. Rio Branco: Embrapa Acre, 2001. (Circular técnica, 41).

VALLE, C. B.; JANK, L.; RESENDE, R. M. S. O melhoramento de forrageiras tropicais no Brasil. Revista Ceres, Viçosa, v. 56, n. 4, p. 460-472, 2009.

VOLPE, E. et al. Acúmulo de forragem e características do solo e da planta no estabelecimento de capim-massai com diferentes níveis de saturação por bases, fósforo e nitrogênio. Revista Brasileira de Zootecnia, Viçosa, v. 37, n. 2, p. 228-237, 2008. 